\section{Show your daughters the joys of science}

Danai Korre

I still remember how excited I was the first time I 'fixed' my first digital pet, with the most basic electric circuit and when I made an LED flicker by using code and a singleboard microcontroller. I believe that watching my dad in his workshop got me interested in electronics and many more technical things after that. I used to sneak into the workshop and play around when he wasn't looking. These early experiences paid off as I am now a PhD student in informatics, and I have a masters degree in Design and Digital Media.

\section{I think academia and research are} predominantly diverse working environments, or at least that is how it seems to me, compared with my working experience outside academia. Gender equality in STEM (science, technology, engineering and mathematics) is a different issue that could be traced to systemic sexism imprinted in women's minds through society and media. There is a stereotype which says that women are not as good as their male counterparts on technical issues or roles. A male acquaintance once proposed that women are unfit for such positions, because their brains "work differently and men are better in math and technical issues". Tell that to Ada Lovelace and Grace Hopper and the long list of successful women who thrived in such positions. If our brains work differently - and the evidence for this isn't good (see Fine, 2010; Rippon et al., 2014) wouldn't having more women in STEM lead to even more amazing accomplishments for the whole of humanity?

Maybe if we want more women in STEM we should treat them equally and inform them about this from the first days of their lives. We prepare our girls to be princesses and we prepare our boys to become leaders while we should prepare them both to be great.

Women need to grow up knowing that they should not be objectified, they are not the 'damsel in distress' type of princesses waiting for a strong male figure to save them, but more like Amazon princesses, strong, confident and ready to take on the world. We need to educate women about other strong women that made a change in this world. We also need more male feminists to get more females into STEM. We need men who will not be threatened by a strong woman or think less of her, and men that will help raise that strong woman. Parents play an important role in technology career choices, so it is important that they are well informed (van Tuijl \& van der Molen, 2016).

\section{Ingredients}

- A working Internet connection.

- An open mind.

\section{Method}

1. If you have a little girl, tell her about the marvellous women that came before 


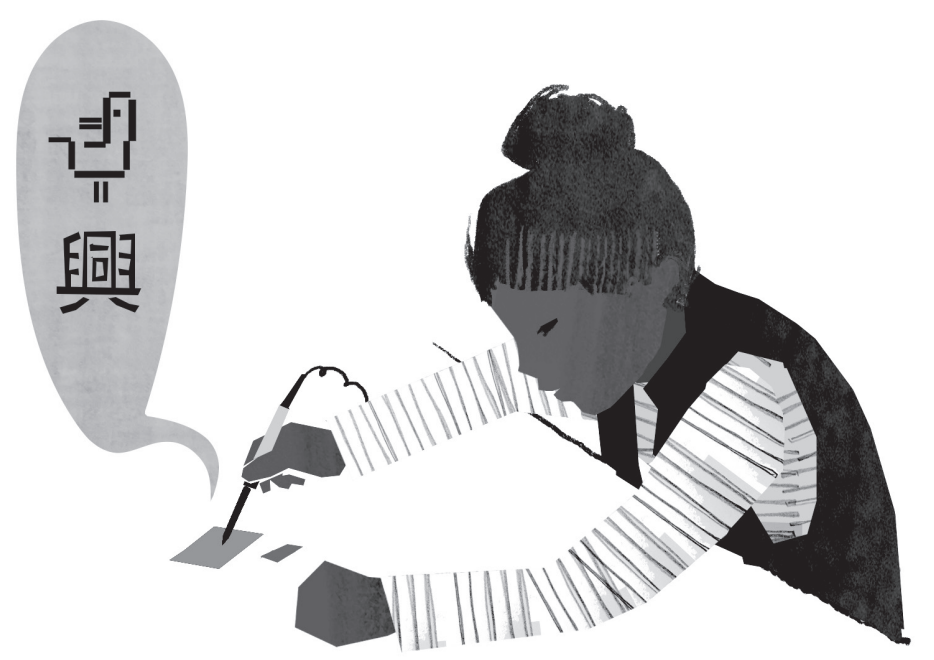

her and made this world a bit better. If you can't think of any beyond Marie Curie, this will get you started: http:// www.smithsonianmag.com/sciencenature/ten-historic-female-scientistsyou-should-know-84028788/?no-ist. You could read the book "Women in Science: 50 Fearless Pioneers Who Changed the World" with her (Ignotofsky, 2017).

2. If you have a boy, do the same.

3. Let them both get their hands dirty and play around with tools. My dad had a small workshop with a soldering station where I made my first solder rings (sounds dangerous I know) and braided bracelets out of colourful telecommunication cables.

4. Take them to a museum or observatory with a hands-on approach. The Edinburgh International Science Festival (https://www.sciencefestival.co.uk/) and the Royal Observatory Edinburgh (http:// www.roe.ac.uk/) are great for this.

5. Make it a game to build something together, like programming a singleboard microcontroller or a (safe) chemical experiment. Try https:// code.org/ for computer programming activities, or try http://makezine.com/ for electronics and making activities.

6. Be aware of how toys are marketed to children. Why should toys or books in shops be labelled 'for boys' or 'for girls'? It's a problem if girls see science and engineering toys labelled for other people but not for them. For that matter, it is a problem that boys should be led to believe that toys related to cooking and caring are not for them. Draw your children's attention to this unfair marketing and discuss it with them: provoke their sense of unfairness. For further information, see http://www. lettoysbetoys.org.uk/why-it-matters/

The annual Edinburgh International Science Festival has a great children's programme full of hands-on science and technology activities. In 2016, 200 university staff and students contributed to a range of events on topics including space, genetics and robotics (http://www.ed.ac.uk/events/festivals/highlights/ all-events/2016/science-festival-interview-with-dr-janet-paterson). 